\title{
Ornithofauna of Ardahan Province (Turkey)
}

\author{
Erkan AZİZOĞLU ${ }^{*}$, Özdemir ADIZEL ${ }^{2}$ \\ ${ }^{l}$ Hakkari Üniversitesi, Çölemerik Meslek Yüksek Okulu, Bitkisel ve Hayvansal Üretim Bölümü, Hakkâri \\ ${ }^{2}$ Van Yüzüncü Yll Üniversitesi, Fen Faültesi, Biyoloji Bölümü, Van \\ (ORCID: 0000-0002-4895-4298) (ORCID: 0000-0002-0432-0277)
}

\begin{abstract}
In this research, bird species in Ardahan Province were examined. The research which kept nearly two years occurred between February 2017 and June 2018. Consequently on the observations 175 species and 2 subspecies were listed in 43 families. It was discovered that 40,7\% (sp:72) of these species were residant, $27.7 \%$ (sp: 49) were summer visitors, $9.0 \%$ (sp: 16) were winter visitors and 22.6\% (sp:40) were transit migrant species. Last assessment of these bird species consedering to IUCN criteria; it was seen that 1 species were EN (Endangered), 9 species were NT (Near Threatened), 5 species were VU (Vulnurable), 159 species were LC (Least concern) and 3 species was not in scope. In addition, important bird areas (Kura River, Çıldır Lake, Aktaş Lake, Putka (Sazara) Lake, Kuşuçmaz Lake, Lavaş Lake, Göle Plain and Ardahan Forests) were observed in Ardahan Province.
\end{abstract}

Keywords: Ardahan, Birds, Ornithofauna, Wetland.

\section{Ardahan İli Ornitofaunası (Türkiye)}

\section{Özet}

Bu araştırmada, Ardahan (Turkiye) ̇li’nin kuş türleri incelenmiştir. Yaklaşık iki yıl süren araştırma Şubat 2017Haziran 2018 ayları arasında gerçekleştirildi. Gözlemler sonucunda 43 familyaya ait 175 tür ve 2 alttür listelendi. Bu türlerin \% 40,7 (Tür: 72) Yerli, \% 27,7 (Tür: 49) Yaz ziyaretçisi, \% 9,0 (Tür: 16) Kış ziyaretçisi, \% 22,6 (Tür: 40) Transit göçer olduğu belirlendi. Bu kuş türlerinin IUCN kriterlerine göre değerlendirilmesi sonucunda; 1 türün tehlike altında (EN-Endangered), 9 türün tehlikeye açık (NT-Near threatened), 5 türün Hassas (VU-Vulnerable), 159 türün düşük riskli (LC-Least concern) statüsünde ve 3 türün kapsamda olmadığı görüldü. Ayrıca Ardahan İli için kuşların yoğun görüldüğü önemli kuş alanları (Kura Nehri, Çıldır Gölü, Aktaş Gölü, Putka (Sazara) Gölü, Kuşuçmaz Gölü, Lavaş Gölü, Göle Ovası ve Ardahan Ormanları) da tespit edildi.

Anahtar kelimeler: Ardahan, Kuşlar, Ornitofauna, Sulak alan.

\section{Introduction}

Anatolia is highly rich in biodiversity due to the diverse geographical characteristics and the habitats. The endemism phenomenon, in addition to the rich diversity, enables the natural structure of Anatolia even more attractive. The diversity in natural structures causes Anatolia having a continental characteristic $[1,2]$.

Turkey, constituting a part of the Palearctic region, serves as the bridge between Europe, Asia and Africa on bird migration routes. Our country has a great importance for bird fauna because of having different climatic conditions and different habitats due to the geographical location. Turkey is quite rich also in terms of important bird habitats. Therefore, our country has a very important place for bird species [3].

Ornithological researches conducted in Anatolia date back to the 1880s. The general characteristics of the species observed in our country had been discussed in the study titled "Important Developments in Anatolian Birds", and the general species list was prepared in this report [4]. The first study in our country is "Turkey Birds" which has served as a valuable source for many years to the

"Sorumlu yazar: erkanazizoglu@ hakkari.edu.tr

Geliş Tarihi: 05.02.2020, Kabul Tarihi: 13.03.2020 
ornithologists [5]. Different numbers reported on various dates for the bird list of Turkey is noteworthy. The number of bird species in 1990 was 421, while this number including the random species in 2015 was increased up to 513 [6-9]. Studies on the habitats of conservation and survival of the species increased with the acceleration of ornithological studies and a book titled "Turkey's Important Bird Areas" was published. The information on 79 Important Bird Habitats (IBH) within the boundaries of Turkey was presented in this study which was updated in 2004 [10,11].

Ardahan province has several wetlands that birds frequently visit. Çıldır Lake, Aktas Lake and Ardahan Forests which are among the Important Natural Habitats (INH), are located within the borders of Ardahan province and host many bird species [12]. Many sources indicated that Aktaş Lake is the only habitat in the country where Pelicanus crispus (Dalmatian pelican) and Pelecanus onocrotalus (Great white pelican) breed together [13, 14]. The region provides feeding and breeding opportunities to the species due the hosting many habitat types located in the transition zone of migratory birds. Thus, the region becomes one of the most frequently visiting places of birds. Therefore, the wetland potential and the bird species of the region have been considered worthy to investigate.

\section{Material ve Methods}

This study was conducted in Ardahan province between February 22, 2017 and June 26, 2018 (Figure 1). A total of 40 days of field study was carried out. The research material was the bird species living in the Ardahan province. The list of bird species for Ardahan province was prepared, and the migration status, IUCN criterion, Bern and CITES statuses of each identified species were also investigated. In addition, the important habitats and threats for birds within the province were also identified.

The methods used in detecting the birds of the area were Squares (Raster Carding) [15] and Observation along a Line Transect-Point Observation Method (Point Counts) [16]. Topographic map (scale 1: 25.000), land observation cards, binoculars, telescope, numerator, camera, GPS (Global Positioning System), marsh garments and diagnostic books were used in the studies $[9,18]$.

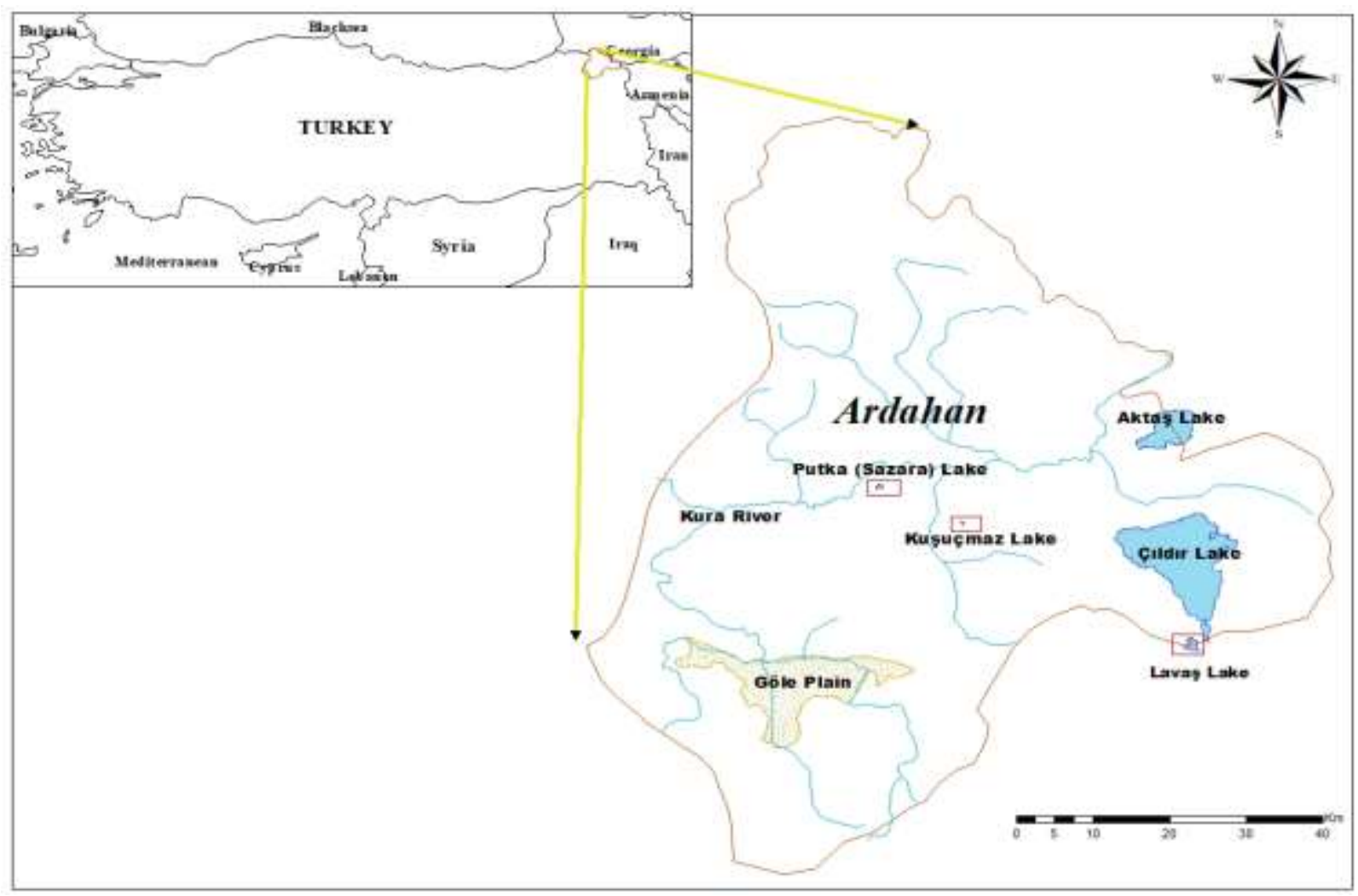

Figure 1. Important bird areas in Ardahan province 


\section{Results}

A total of 177 birds, including 175 bird species belonging to 43 families and 2 (Buteo buteo vulpinusSteppe Buzzard, Motacilla flava feldegg-Masked wagtail) subspecies were identified in the study area. The species determined in the study area composed of Residents 40.7\%, (n: 72), Summer Visitors $27.7 \%$ (n: 49), Winter Visitors $9.0 \%$ (n: 16) and Transit Migrants 22.6\% (n: 40).

The status of species according to IUCN criteria were identified as follows; 1 species is EN (Neophron percnopterus-Egyptian vulture), 4 species is VU (Aythya ferina-Common pochard, Aquila heliaca- Eastern Imperial Eagle, Streptopelia turtur- European turtle-dove, Branta ruficollis, Redbreasted goose) 10 species is NT (Pelecanus crispus- Dalmatian pelican, Aythya nyroca- Ferruginous duck, Gypaetus barbatus- Lammergeier, Aegypius monachus- Cinereous vulture, Falco vespertinusRed-footed falcon, Lyrurus mlokosiewiczi- Caucasian grouse, Haematopus ostralegus-Eurasian oystercatcher, Vanellus vanellus-Northern lapwing, Larus armenicus-Armenian gull, Anthus pratensisMeadow pipit) and 159 species is LC. Three species (Buteo buteo vulpinus- Steppe buzzard, Motacilla flava feldegg-Masked wagtail, Corvus cornix-Carrion crow) could not listed according to IUCN criteria (Table 1).

Table 1. Bird species and their status determined in Ardahan province

\begin{tabular}{|c|c|c|c|c|c|}
\hline Family & Scientific Species Name & English Species Name & IUCN & CITES & $\begin{array}{l}\text { Region } \\
\text { Status }\end{array}$ \\
\hline \multirow{4}{*}{ Podicipedidae } & Tachybaptus ruficollis & Little Grebe & $\mathrm{LC}$ & Out of Scope & $\mathrm{R}$ \\
\hline & Podiceps cristatus & Great Crested Grebe & $\mathrm{LC}$ & Out of Scope & $\mathrm{R}$ \\
\hline & Podiceps grisegena & Red-necked Grebe & $\mathrm{LC}$ & Out of Scope & SV \\
\hline & Podiceps nigricollis & Black-necked Grebe & $\mathrm{LC}$ & Out of Scope & $\mathrm{R}$ \\
\hline \multirow{8}{*}{ Ardeidae } & Ixobrychus minutus & Little Bittern & $\mathrm{LC}$ & Out of Scope & $\mathrm{T}$ \\
\hline & Ardeola ralloides & Squacco Heron & $\mathrm{LC}$ & Out of Scope & SV \\
\hline & Nycticorax nycticorax & Black-crowned Night-heron & $\mathrm{LC}$ & Out of Scope & $\mathrm{T}$ \\
\hline & Bubulcus ibis & Cattle Egret & $\mathrm{LC}$ & Out of Scope & $\mathrm{R}$ \\
\hline & Egretta garzetta & Little Egret & $\mathrm{LC}$ & Out of Scope & WV \\
\hline & Ardea alba & Great Egret & $\mathrm{LC}$ & Out of Scope & $\mathrm{T}$ \\
\hline & Ardea cinerea & Grey Heron & $\mathrm{LC}$ & Out of Scope & $\mathrm{R}$ \\
\hline & Ardea purpurea & Purple Heron & $\mathrm{LC}$ & Out of Scope & $\mathrm{T}$ \\
\hline \multirow{2}{*}{ Pelecanidae } & Pelecanus onocrotalus & Great White Pelican & $\mathrm{LC}$ & Out of Scope & SV \\
\hline & Pelecanus crispus & Dalmatian Pelican & NT & Annex I & $\mathrm{R}$ \\
\hline Phalacrocoracidae & Phalacrocorax carbo & Great Cormorant & $\mathrm{LC}$ & Out of Scope & WV \\
\hline Threskiornithidae & Plegadis falcinellus & Glossy Ibis & $\mathrm{LC}$ & Out of Scope & $\mathrm{R}$ \\
\hline \multirow{2}{*}{ Ciconiidae } & Ciconia nigra & Black Stork & $\mathrm{LC}$ & Annex II & $\mathrm{T}$ \\
\hline & Ciconia ciconia & White Stork & $\mathrm{LC}$ & Out of Scope & SV \\
\hline \multirow{14}{*}{ Anatidae } & Anser albifrons & Greater White-fronted Goose & $\mathrm{LC}$ & Out of Scope & $\mathrm{T}$ \\
\hline & Anser anser & Greylag Goose & $\mathrm{LC}$ & Out of Scope & SV \\
\hline & Branta ruficollis & Red-breasted Goose & VU & Annex II & $\mathrm{T}$ \\
\hline & Tadorna ferruginea & Ruddy Shelduck & $\mathrm{LC}$ & Out of Scope & SV \\
\hline & Mareca strepera & Gadwall & $\mathrm{LC}$ & Out of Scope & $\mathrm{R}$ \\
\hline & Anas crecca & Common Teal & $\mathrm{LC}$ & Out of Scope & $\mathrm{R}$ \\
\hline & Anas platyrhynchos & Mallard & $\mathrm{LC}$ & Out of Scope & $\mathrm{R}$ \\
\hline & Anas acuta & Northern Pintail & $\mathrm{LC}$ & Out of Scope & $\mathrm{T}$ \\
\hline & Spatula querquedula & Garganey & $\mathrm{LC}$ & Out of Scope & SV \\
\hline & Spatula clypeata & Northern Shoveler & $\mathrm{LC}$ & Out of Scope & SV \\
\hline & Aythya ferina & Common Pochard & VU & Out of Scope & $\mathrm{R}$ \\
\hline & Aythya nyroca & Ferruginous Duck & NT & Out of Scope & $\mathrm{R}$ \\
\hline & Aythya fuligula & Tufted Duck & $\mathrm{LC}$ & Out of Scope & $\mathrm{R}$ \\
\hline & Aythya marila & Greater Scaup & $\mathrm{LC}$ & Out of Scope & WV \\
\hline \multirow{3}{*}{ Accipitridae } & Milvus migrans & Black Kite & $\mathrm{LC}$ & Annex II & $\mathrm{T}$ \\
\hline & Gypaetus barbatus & Lammergeier & NT & Annex II & $\mathrm{R}$ \\
\hline & Neophron percnopterus & Egyptian Vulture & $\mathrm{EN}$ & Annex II & $\mathrm{R}$ \\
\hline
\end{tabular}




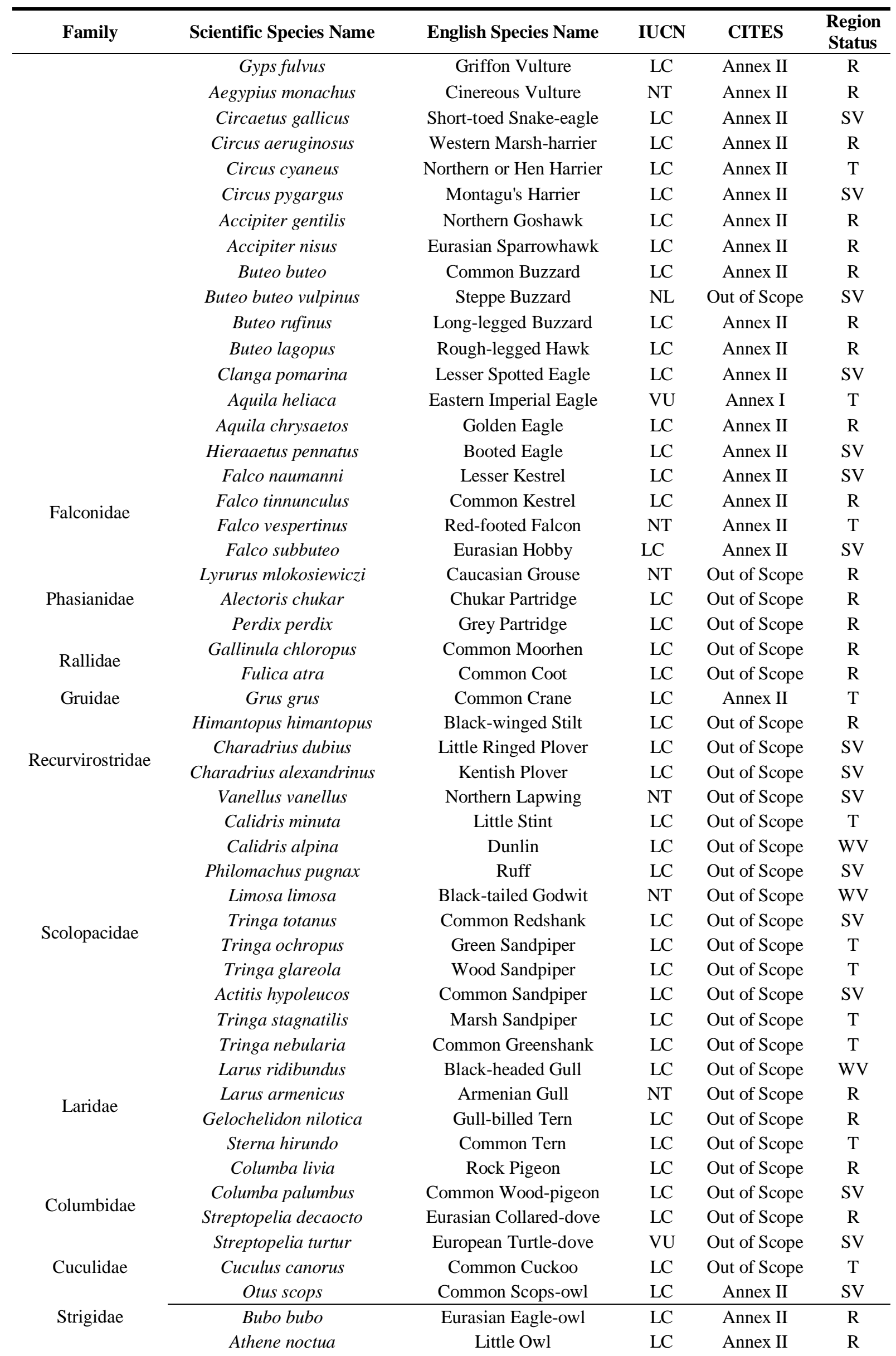




\begin{tabular}{|c|c|c|c|c|c|}
\hline Family & Scientific Species Name & English Species Name & IUCN & CITES & $\begin{array}{l}\text { Region } \\
\text { Status }\end{array}$ \\
\hline \multirow{4}{*}{ Apodidae } & Asio otus & Long-eared Owl & $\mathrm{LC}$ & Annex II & $\mathrm{R}$ \\
\hline & Asio flammeus & Short-eared Owl & $\mathrm{LC}$ & Annex II & $\mathrm{R}$ \\
\hline & Apus apus & Common Swift & $\mathrm{LC}$ & Out of Scope & SV \\
\hline & Tachymarptis melba & Alpine Swift & $\mathrm{LC}$ & Out of Scope & $\mathrm{T}$ \\
\hline Meropidae & Merops apiaster & European Bee-eater & $\mathrm{LC}$ & Out of Scope & $\mathrm{T}$ \\
\hline Coraciidae & Coracias garrulus & European Roller & $\mathrm{LC}$ & Out of Scope & $\mathrm{T}$ \\
\hline Upupidae & Upupa epops & Eurasian Hoopoe & $\mathrm{LC}$ & Out of Scope & SV \\
\hline \multirow[t]{3}{*}{ Picidae } & Dendrocopos syriacus & Syrian Woodpecker & $\mathrm{LC}$ & Out of Scope & $\mathrm{R}$ \\
\hline & Melanocorypha calandra & Calandra Lark & $\mathrm{LC}$ & Out of Scope & $\mathrm{R}$ \\
\hline & Melanocorypha bimaculata & Bimaculated Lark & $\mathrm{LC}$ & Out of Scope & $\mathrm{R}$ \\
\hline \multirow{4}{*}{ Alaudidae } & Galerida cristata & Crested Lark & $\mathrm{LC}$ & Out of Scope & $\mathrm{R}$ \\
\hline & Lullula arborea & Wood Lark & $\mathrm{LC}$ & Out of Scope & WV \\
\hline & Alauda arvensis & Eurasian Skylark & $\mathrm{LC}$ & Out of Scope & WV \\
\hline & Eremophila alpestris & Horned Lark & $\mathrm{LC}$ & Out of Scope & $\mathrm{R}$ \\
\hline \multirow{5}{*}{ Hirundinidae } & Riparia riparia & Sand Martin & $\mathrm{LC}$ & Out of Scope & SV \\
\hline & Ptyonoprogne rupestris & Eurasian Crag & $\mathrm{LC}$ & Out of Scope & SV \\
\hline & Hirundo rustica & Barn Swallow & $\mathrm{LC}$ & Out of Scope & SV \\
\hline & Delichon urbicum & Northern House-martin & $\mathrm{LC}$ & Out of Scope & SV \\
\hline & Cecropis daurica & Red-rumped Swallow & $\mathrm{LC}$ & Out of Scope & SV \\
\hline \multirow{9}{*}{ Motacillidae } & Anthus campestris & Tawny Pipit & $\mathrm{LC}$ & Out of Scope & SV \\
\hline & Anthus pratensis & Meadow Pipit & NT & Out of Scope & $\mathrm{T}$ \\
\hline & Anthus cervinus & Red-throated Pipit & $\mathrm{LC}$ & Out of Scope & SV \\
\hline & Anthus spinoletta & Water Pipit & $\mathrm{LC}$ & Out of Scope & $\mathrm{R}$ \\
\hline & Motacilla flava & Yellow Wagtail & $\mathrm{LC}$ & Out of Scope & SV \\
\hline & Motacilla flava feldegg & Masked Wagtail & NL & Out of Scope & SV \\
\hline & Motacilla citreola & Citrine Wagtail & $\mathrm{LC}$ & Out of Scope & $\mathrm{T}$ \\
\hline & Motacilla cinerea & Grey Wagtail & $\mathrm{LC}$ & Out of Scope & WV \\
\hline & Motacilla alba & White Wagtail & $\mathrm{LC}$ & Out of Scope & $\mathrm{R}$ \\
\hline Cinclidae & Cinclus cinclus & White-throated Dipper & $\mathrm{LC}$ & Out of Scope & $\mathrm{R}$ \\
\hline Troglodytidae & Troglodytes troglodytes & Winter Wren & $\mathrm{LC}$ & Out of Scope & $\mathrm{T}$ \\
\hline Prunellidae & Prunella modularis & Hedge Accentor & $\mathrm{LC}$ & Out of Scope & $\mathrm{R}$ \\
\hline \multirow{12}{*}{ Muscicapidae } & Muscicapa striata & Spotted Flycatcher & $\mathrm{LC}$ & Out of Scope & $\mathrm{T}$ \\
\hline & Cercotrichas galactotes & Rufous-tailed Scrub-robin & $\mathrm{LC}$ & Out of Scope & $\mathrm{T}$ \\
\hline & Erithacus rubecula & European Robin & $\mathrm{LC}$ & Out of Scope & $\mathrm{T}$ \\
\hline & Luscinia megarhynchos & Common Nightingale & $\mathrm{LC}$ & Out of Scope & SV \\
\hline & Phoenicurus ochruros & Black Redstart & $\mathrm{LC}$ & Out of Scope & WV \\
\hline & Phoenicurus phoenicurus & Common Redstart & $\mathrm{LC}$ & Out of Scope & SV \\
\hline & Saxicola rubetra & Whinchat & $\mathrm{LC}$ & Out of Scope & $\mathrm{T}$ \\
\hline & Saxicola torquatus & Common Stonechat & $\mathrm{LC}$ & Out of Scope & WV \\
\hline & Oenanthe isabellina & Isabelline Wheatear & $\mathrm{LC}$ & Out of Scope & SV \\
\hline & Oenanthe oenanthe & Northern Wheatear & $\mathrm{LC}$ & Out of Scope & $\mathrm{T}$ \\
\hline & Oenanthe hispanica & Black-eared Wheatear & $\mathrm{LC}$ & Out of Scope & SV \\
\hline & Monticola saxatilis & Rufous-tailed Rock-thrush & $\mathrm{LC}$ & Out of Scope & $\mathrm{R}$ \\
\hline \multirow{3}{*}{ Turdidae } & Turdus torquatus & Ring Ouzel & $\mathrm{LC}$ & Out of Scope & $\mathrm{R}$ \\
\hline & Turdus merula & Eurasian Blackbird & $\mathrm{LC}$ & Out of Scope & $\mathrm{R}$ \\
\hline & Turdus viscivorus & Mistle Thrush & $\mathrm{LC}$ & Out of Scope & $\mathrm{R}$ \\
\hline \multirow{3}{*}{ Acrocephalidae } & $\begin{array}{c}\text { Acrocephalus } \\
\text { schoenobaenus }\end{array}$ & Sedge Warbler & $\mathrm{LC}$ & Out of Scope & SV \\
\hline & Acrocephalus scirpaceus & Eurasian Reed-warbler & $\mathrm{LC}$ & Out of Scope & SV \\
\hline & Acrocephalus arundinaceus & Great Reed-warbler & $\mathrm{LC}$ & Out of Scope & $\mathrm{T}$ \\
\hline \multirow{3}{*}{ Sylviidae } & Sylvia melanocephala & Sardinian Warbler & $\mathrm{LC}$ & Out of Scope & $\mathrm{T}$ \\
\hline & Sylvia curruca & Lesser Whitethroat & $\mathrm{LC}$ & Out of Scope & $\mathrm{T}$ \\
\hline & Sylvia communis & Common Whitethroat & $\mathrm{LC}$ & Out of Scope & $\mathrm{T}$ \\
\hline
\end{tabular}




\begin{tabular}{|c|c|c|c|c|c|}
\hline Family & Scientific Species Name & English Species Name & IUCN & CITES & $\begin{array}{l}\text { Region } \\
\text { Status }\end{array}$ \\
\hline \multirow{3}{*}{ Phylloscopidae } & Sylvia atricapilla & Blackcap & $\mathrm{LC}$ & Out of Scope & WV \\
\hline & Phylloscopus collybita & Common Chiffchaff & $\mathrm{LC}$ & Out of Scope & $\mathrm{R}$ \\
\hline & Phylloscopus trochilus & Willow Warbler & $\mathrm{LC}$ & Out of Scope & $\mathrm{T}$ \\
\hline \multirow{4}{*}{ Paridae } & Periparus ater & Coal Tit & $\mathrm{LC}$ & Out of Scope & $\mathrm{R}$ \\
\hline & Cyanistes caeruleus & Blue Tit & $\mathrm{LC}$ & Out of Scope & $\mathrm{R}$ \\
\hline & Parus major & Great Tit & $\mathrm{LC}$ & Out of Scope & $\mathrm{R}$ \\
\hline & Sitta krueperi & Krueper's Nuthatch & $\mathrm{LC}$ & Out of Scope & $\mathrm{R}$ \\
\hline \multirow[t]{2}{*}{ Sittidae } & Sitta europaea & Wood Nuthatch & $\mathrm{LC}$ & Out of Scope & $\mathrm{T}$ \\
\hline & Sitta neumayer & Western Rock-nuthatch & $\mathrm{LC}$ & Out of Scope & $\mathrm{R}$ \\
\hline \multirow[t]{2}{*}{ Certhiidae } & Certhia brachydactyla & Short-toed Treecreeper & $\mathrm{LC}$ & Out of Scope & $\mathrm{R}$ \\
\hline & Lanius excubitor & Great Grey Shrike & $\mathrm{LC}$ & Out of Scope & WV \\
\hline \multirow{3}{*}{ Laniidae } & Lanius collurio & Red-backed Shrike & $\mathrm{LC}$ & Out of Scope & SV \\
\hline & Lanius minor & Lesser Grey Shrike & $\mathrm{LC}$ & Out of Scope & SV \\
\hline & Lanius senator & Woodchat Shrike & $\mathrm{LC}$ & Out of Scope & $\mathrm{T}$ \\
\hline \multirow{6}{*}{ Corvidae } & Garrulus glandarius & Eurasian Jay & $\mathrm{LC}$ & Out of Scope & $\mathrm{R}$ \\
\hline & Pica pica & Black-billed Magpie & $\mathrm{LC}$ & Out of Scope & $\mathrm{R}$ \\
\hline & Corvus monedula & Eurasian Jackdaw & $\mathrm{LC}$ & Out of Scope & $\mathrm{R}$ \\
\hline & Corvus frugilegus & Rook & $\mathrm{LC}$ & Out of Scope & $\mathrm{R}$ \\
\hline & Corvus cornix & Carrion Crow & NL & Out of Scope & $\mathrm{R}$ \\
\hline & Corvus corax & Common Raven & $\mathrm{LC}$ & Out of Scope & $\mathrm{R}$ \\
\hline \multirow{2}{*}{ Sturnidae } & Sturnus vulgaris & Common Starling & $\mathrm{LC}$ & Out of Scope & WV \\
\hline & Pastor roseus & Rosy Starling & $\mathrm{LC}$ & Out of Scope & SV \\
\hline \multirow{3}{*}{ Passeridae } & Passer domesticus & House Sparrow & $\mathrm{LC}$ & Out of Scope & $\mathrm{R}$ \\
\hline & Petronia petronia & Rock Sparrow & $\mathrm{LC}$ & Out of Scope & $\mathrm{R}$ \\
\hline & Montifringilla nivalis & White-winged Snowfinch & $\mathrm{LC}$ & Out of Scope & SV \\
\hline \multirow{7}{*}{ Fringillidae } & Fringilla coelebs & Eurasian Chaffinch & $\mathrm{LC}$ & Out of Scope & $\mathrm{R}$ \\
\hline & Fringilla montifringilla & Brambling & $\mathrm{LC}$ & Out of Scope & $\mathrm{T}$ \\
\hline & Chloris chloris & European Greenfinch & $\mathrm{LC}$ & Out of Scope & $\mathrm{R}$ \\
\hline & Carduelis carduelis & European Goldfinch & $\mathrm{LC}$ & Out of Scope & $\mathrm{R}$ \\
\hline & Linaria cannabina & Eurasian Linnet & $\mathrm{LC}$ & Out of Scope & $\mathrm{R}$ \\
\hline & Carpodacus erythrinus & Common Rosefinch & $\mathrm{LC}$ & Out of Scope & SV \\
\hline & Pyrrhula pyrrhula & Eurasian Bullfinch & $\mathrm{LC}$ & Out of Scope & WV \\
\hline \multirow{6}{*}{ Emberizidae } & Emberiza citrinella & Yellowhammer & $\mathrm{LC}$ & Out of Scope & WV \\
\hline & Emberiza cia & Rock Bunting & $\mathrm{LC}$ & Out of Scope & SV \\
\hline & Emberiza hortulana & Ortolan Bunting & $\mathrm{LC}$ & Out of Scope & SV \\
\hline & Emberiza buchanani & Grey-necked Bunting & $\mathrm{LC}$ & Out of Scope & $\mathrm{T}$ \\
\hline & Emberiza melanocephala & Black-headed Bunting & $\mathrm{LC}$ & Out of Scope & SV \\
\hline & Emberiza calandra & Corn Bunting & $\mathrm{LC}$ & Out of Scope & $\mathrm{R}$ \\
\hline
\end{tabular}

R: Residant, WV: Winter Visitors, SV: Summer Visitors, T: Transit Göçer, LC: Least Concern, NT: Near Threatened, VU: Vulnerable, EN: Endangered NL: Not Listed

The results indicated 8 important habitats in Ardahan province that are frequently visited by the birds. These areas are Kura River, Çıldır Lake, Aktaş Lake, Putka (Sazara) Lake, Kuşuçmaz Lake, Lavaş Lake, Göle Plain and Ardahan Forests (Figure 1). The species identified use these areas for resting, safety, breeding, feeding and daily displacement activities. In addition, factors threatening both these areas and the livings in these areas were also investigated.

\section{Discussion and Conclusion}

In this study 177 bird species were identified in the study area. The population of little vulture (Neophron percnopterus) and the Dalmatian pelican (Pelecanus crispus) bird species is globally decreasing according to IUCN list. Common pochard (Aythya farina), Turtle dove (Streptopelia turtur) and Siberian goose (Branta ruficollis) included in VU status (Vulnerable), are hunted in the region. These species are 
under a heavy hunting pressure. Eastern Imperial Eagle (Aquila heliaca) is another rarely observed endangered species. One hundred twenty one of the 177 bird species identified in the area breed within the province borders.

Eight habitats were determined as commonly preferred areas of the birds in Ardahan province. Dalmatian pelican and Great White pelican species incubate together on a small island in Aktaş Lake which is one of the commonly preferred areas of birds in Ardahan. Since both species usually breed in different locations, this is a rarely encountered situation. The simultaneous incubation of two species on the island can be explained by the safety of the island. Wetlands, which are very active in summer, are completely covered by snow in winter months.

Aktaş Lake has been reported as the breeding place especially for the Dalmatian pelicans (Pelecanus crispus) and that 20 to 35 couples are reported constantly breeding [12-14]. Our study confirmed the importance of Aktaş Lake for pelican species once more. Pelicans were observed breeding on islands in the lake and spreading throughout the lake basin.

The number of bird species recently has increased higly with the acceleration of ornithological studies in Turkey. The number of bird species in Turkey ornitofauna was initially reported as 421 in 1990. The number has increased to 513 bird species including the most recent random species due to the increasing number reports of from researchers [6-9]. The species obtained in our study completely coincide with the species reported in the previous studies. However, some differences in distribution and status have also been encountered. In addition, the number of bird species is expected to increase with the future studies conducted in Ardahan province.

Many living species are threatened with extinction worldwide due to various reasons. Habitat problems are the primary causes for the extinction of living species. The degraded or weakened habitat characteristics and habitat losses accelerate the extinction process. Therefore, the bird species identified within the borders of Ardahan province should be conserved together with their habitats. Greater attention should be given to the habitats where endangered species live. The results revealed that Kura River, Çıldır Lake, Aktaş Lake, Putka (Sazara) Lake, Kuşuçmaz Lake, Lavaş Lake, Göle Plain and Ardahan Forests are the important habitats within the province and need to be carefully conserved.

The influence of an important bird migration route and containing the habitats attracting birds reveals the ornithological importance of Ardahan province. The regions where the population of birds and other wild animals are dense are mostly under human and domestic animal pressure. Hunting, agricultural activities, reed cutting, grazing, drainage and drying were as identified as the major elements of destuction in the study area.

\section{Acknowledgement}

This study was summarized from the "Ardahan Province Terrestrial and Inland Water Ecosystems Biological Diversity and Inventory Monitoring Project" carried out by the Republic of Turkey, Ministry of Agriculture and Forestry, General Directorate of Nature Conservation and National Parks. We would like to thank for their contributions.

\section{Author's Contributions}

Erkan AZİZOĞLU and Özdemir ADIZEL designed the study, performed identification of bird species, data analysis and writing of the manuscript.

\section{Statement of Conflicts of Interest}

The authors declare that there is no conflict of interest.

\section{Statement of Research and Publication Ethics}

The authors declares that this study complies with Research and Publication Ethics. 


\section{References}

[1] Kiziroğlu İ. 2001. Ekolojik Potpuri. TAKAV Mat. Yay. A.Ş. 391s, Ankara.

[2] Meriç B.T., Çığarankaya S. 2013. Sulak Alanlar, Orman ve Su İşleri Bakanlığı, Doğa Koruma ve Milli Parklar Genel Müdürlüğ̈̈, Hassas Alanlar Daire Başkanlığı, Sulak Alanlar Şube Müdürlügü̆, Ankara.

[3] Kaya M., Yurtsever S., Kurtoner C. 1999. Trakya Ornito-faunası üzerine araştırmalar I. Turkish Journal of Zoology, 23 (Ek Say1 3): 781-790.

[4] Danfort Ch. G. 1880. A Further Contribution to the Ornithhology of Asia Minor. Ibis, IV: 81-89.

[5] Ergene S. 1945. Türkiye Kuşları. İst. Ünv. Fen Fak. Monogafileri, İstanbul, 4: 361.

[6] Turan L. 1990. Türkiye'nin Av ve Yaban Hayvanları/Kuşlar. Eğitim Daire Başkanlığı, Yayın ve Tanıtma Şube Müdürlüğü, Ankara,

[7] Kasparek M., Bilgin C. 1996. Kuşlar (Aves): Türkiye Omurgalılar Tür Listesi. Tübitak, Ankara, 26-87.

[8] Kirwan G., Demirci B., Welch H., Boyla K.A., Özen M., Castell P., Marlow T. 1998. The Birds of Turkey. Christopher Helm, London, 312s.

[9] Kiziroğlu İ. 2015. Türkiye Kuşları Cep Kitabı. Sarıyıldız Ofset ve Matbaacılık, Ankara, 577s.

[10] Yarar M., Magnin G. 1997. Türkiye'nin Önemli Kuş Alanları. Doğal Hayatı Koruma Derneği, İstanbul, 313s.

[11] Kılıç T.D., Eken G. 2004. Türkiye'nin Önemli Kuş Alanları. Doğa Derneği, Ankara, 133-134s.

[12] Eken G., Bozdoğan M., Isfendiaroğlu S., Kiliç D.T., Lise Y. 2006. Türkiye'nin önemli doğa alanları [Key Biodiversity Areas of Turkey]. Doğa Derneği, Ankara.

[13] Yarar M. 1995. Akta Gölü: a new pelican breeding site on the Turkish-Georgian border. Bulletin of the Ornithological Society of the Middle East, 35: 46-48.

[14] Onmuş O., S1kı M., Sarıgül G., Crivelli A.J. 2011. Status and development of the population of the globally threatened Dalmatian Pelican, Pelecanus crispus, in Turkey. Zoology in the Middle East, 54 (1): 3-17.

[15] Dobinson H.M. 1976. Bird Count, Keztrel Books. Published by Penguin Books Ltd, Hormondsworth, İstanbul, 55s.

[16] Bibby C.J., Burgess N.D. 1992. Bird Census Techniques. Academic Pres Limited, NW1 7DX, London, 257s.

[17] Sevnsson L., Mullarney K., Zatterström D. 2009. Collins Bird Guide. Harper Collins Publishers Ltd., Fulham Palace Road, London, 77-85s. 